\title{
Dissemination and genetic analysis of the stealthy vanB gene clusters of Enterococcus faecium clinical isolates in Japan
}

\author{
Yusuke Hashimoto', Jun Kurushima'1, Takahiro Nomura', Koichi Tanimoto², Kiyoko Tamai ${ }^{3}$, Hideji Yanagisawa ${ }^{3}$,
} Komei Shirabe ${ }^{4}$, Yasuyoshi Ike ${ }^{1}$ and Haruyoshi Tomita ${ }^{1,2^{*}}$ (i)

\begin{abstract}
Background: VanB-type vancomycin (VAN) resistance gene clusters confer VAN resistances on Enterococcus spp. over a wide range of MIC levels (MIC $=4-1000 \mathrm{mg} / \mathrm{L}$ ). However, the epidemiology and the molecular characteristics of the VAN susceptible VanB-type Enterococcus still remain unclear.

Results: We characterized 19 isolates of VanB-type Enterococcus faecium that might colonize in the gut and were not phenotypically resistant to VAN (MIC $=3 \mathrm{mg} / \mathrm{L}$ ). They were obtained from two hospitals in Japan between 2009 and 2010. These isolates had the identical vanB gene cluster and showed same multilocus sequence typing (MLST) (ST78) and the highly related profiles in pulsed-field gel electrophoresis (PFGE). The vanB gene cluster was located on a plasmid, and was transferable to E. faecium and E. faecalis. Notably, from these VanB-type VREs, VAN resistant (MIC $\geq 16 \mathrm{mg} / \mathrm{L}$ ) mutants could appear at a frequency of $10^{-6}-10^{-7} /$ parent cell in vitro. Most of these revertants acquired mutations in the $v_{a n S}$ gene, while the remainder of the revertants might have other mutations outside of the vanB gene cluster. All of the revertants we tested showed increases in the VAN-dependent expression of the vanB gene cluster, suggesting that the mutations affected the transcriptional activity and increased the VAN resistance. Targeted mutagenesis revealed that three unique nucleotide substitutions in the vanB gene cluster of these strains attenuated VAN resistance.

Conclusions: In summary, this study indicated that stealthy VanB-type E. faecium strains that have the potential ability to become resistance to VAN could exist in clinical settings.
\end{abstract}

Keywords: VRE, Antibiotic resistance, Outbreak, Conjugation, Reversion

\section{Background}

Enterococcus spp. is a typical opportunistic pathogen causing urinary tract infections, bloodstream infections and surgical site infections in compromised hosts. Vancomycin (VAN) is a glycopeptide antibiotic that inhibits peptidoglycan synthesis and is used to treat severe Gram-positive bacterial infections [1]. VAN resistance clusters were distributed among several enterococcal species [2]. Notably, the most of VAN resistant enterococci (VRE) are Enterococcus faecalis and Enterococcus

\footnotetext{
*Correspondence: tomitaha@gunma-u.ac.jp

'Department of Bacteriology, Gunma University Graduate School of Medicine, 3-39-22 Showa-machi, Maebashi, Gunma 371-8511, Japan 2Laboratory of Bacterial Drug Resistance, Gunma University Graduate School of Medicine, 3-39-22 Showa-machi, Maebashi, Gunma 371-8511, Japan
} Full list of author information is available at the end of the article faecium. VRE was first reported in England and France in 1986 [3, 4] and is now one of the major nosocomial pathogens in the world [5]. Due to the limited options for treatment, invasive infections by this pathogen are important causes of mortality. For that reason, the active surveillance is being carried out to prevent the spread of VRE [6]. The VAN resistance in VRE are classified into eight acquired gene clusters. These are $\operatorname{van} A$, vanB, vanD, vanE, vanG, vanL, vanM and vanN [2]. VanA- and VanB-type VRE make up of a majority of VRE and most important in clinical settings. VanA-type VRE shows a high resistance to both VAN (MIC $=64-100 \mathrm{mg} / \mathrm{L}$ ) and teicoplanin (TEC) $(\mathrm{MIC}=16-512 \mathrm{mg} / \mathrm{L})$, whereas VanB-type VRE shows a susceptibility to TEC (MIC $=0.5-1 \mathrm{mg} / \mathrm{L})$ and various levels of resistance to VAN (MIC $=4-1000 \mathrm{mg} / \mathrm{L})$ [6]. The

(c) The Author(s). 2018 Open Access This article is distributed under the terms of the Creative Commons Attribution 4.0 International License (http://creativecommons.org/licenses/by/4.0/), which permits unrestricted use, distribution, and 
$\operatorname{vanB}$ gene cluster consists of a two-component regulatory system $\left(\operatorname{vanR}_{B}, \operatorname{van}_{B}\right)$ and five resistance genes $\left(\operatorname{van} Y_{B}\right.$, van $W, \operatorname{van}_{B}$, vanB, van $X_{B}$ ) (Fig. 1) [7]. Contrary to the highly conserved resistance genes, the amino acid sequences of $\operatorname{VanS}_{\mathrm{B}}$ and $\mathrm{VanR}_{\mathrm{B}}$ show less similarities to those of VanS and VanR (vanA gene cluster) with 34 and 23\% identities, respectively [8]. These differences are suspected to be responsible for the characteristics of VanB-type resistance [8]. Outbreaks of VanB-type VRE occurred in Europe, USA and worldwide $[5,9,10]$. The wide range of VAN resistance of VanB-type VRE (MIC $=4-1000 \mathrm{mg} / \mathrm{L}$ ) makes it more difficult to detect in clinical settings. A previous study reported that $55 \%$ of VanB-type VRE isolated in an outbreak in the neonatal ICU of a German hospital showed low MICs of VAN (less than $4 \mathrm{mg} / \mathrm{L}$ ) [9]. Meanwhile, there is concern that such low-level VRE may cause treatment failure due to its conversion to a high level of resistance [11]. Indeed, it has been reported that low-level VAN resistant $E$. faecium became VAN resistant during antibiotic therapy and this was named vancomycin-variable $E$. faecium (VVE) [12-14]. In Japan, the first VRE was VanA-type E. faecium isolated in 1996 [15] and the first outbreak of VRE was caused by VanB-type E. faecium [16]. Although the prevalence of VRE is presumed to be low in Japan in comparison with those in other countries, little is known about the prevalence of VanB-type VRE with low-level VAN resistance. In this study, we characterized E. faecium isolates that harbored the $\operatorname{van} B$ gene clusters but were not resistant to VAN (MIC $=3 \mathrm{mg} / \mathrm{L}$ ), and performed genetic analysis to assess the responsible determinants for the attenuated VAN resistance of their $\operatorname{vanB}$ gene clusters.

\section{Results}

\section{Isolation of VAN susceptible $E$. faecium harboring the vanB gene cluster}

In 2009 and 2010, a total of nineteen VAN susceptible $E$. faecium strains that harbored the $\operatorname{vanB}$ gene cluster were isolated from the feces of individual in-patients during a VRE screening test at two hospitals located in adjacent prefectures in Japan. We designated ten isolates as M1-M10 from Hospital A and nine as Y7-Y15 from Hospital B, respectively (Table 1). All the patients did not show any significant symptoms of bacterial infectious diseases and were carriers. The VanB-type VAN resistance genes were detected by PCR. All of the 19 isolates were susceptible to VAN $(\mathrm{MIC}=3 \mathrm{mg} / \mathrm{L})$ and TEC $(\mathrm{MIC}=1 \mathrm{mg} / \mathrm{L})$, and resistant to ampicillin $(\mathrm{MIC} \geq 128 \mathrm{mg} / \mathrm{L})$, tetracycline $(\mathrm{MIC}=64 \mathrm{mg} / \mathrm{L})$, erythromycin $(\mathrm{MIC}>256 \mathrm{mg} / \mathrm{L})$ and ciprofloxacin $(\mathrm{MIC}=64 \mathrm{mg} / \mathrm{L})$ (Table 1). To determine the correlation between their genetic backgrounds, we performed PFGE and MLST analysis (Fig. 2, Table 1). Based on the results from PFGE analysis, these 19 isolates were classified into three main clusters (I, II, and III) with an $85 \%$ similarity value as cutoff point. Clusters I was further divided into three sub-clusters (I-A, I-B, and I-C) based on a $90 \%$ of similarity value. Y7-Y15 strains obtained from hospital B were all categorized into cluster II, showing that they were highly related in PFGE pattern. Compared with the Y-series strains, M-series strains obtained from hospital A showed wider genetic variation, although they were clustered and had more than $85 \%$ similarity values. MLST showed that these 19 isolates belonged to a ST78 lineage (allelic profile, 15-1-1-1-1-1-1), indicating that all these VAN susceptible E. faecium strains with the vanB gene cluster had a similar genetic background, but there was a slight genetic variation.

\section{Single nucleotide variations (SNVs) in vanB gene cluster of VAN susceptible isolates}

To identify the determinants for attenuated VAN resistance in the M1-M10 and Y7-Y15 strains, we analyzed the nucleotide sequences of the $\operatorname{van} B$ gene clusters in $\mathrm{M} 1$ and Y7, which were the first isolates detected in the respective hospitals (Fig. 1, Table 2). The nucleotide sequences of the $v a n B$ gene clusters of these strains were completely identical. Then we compared the nucleotide

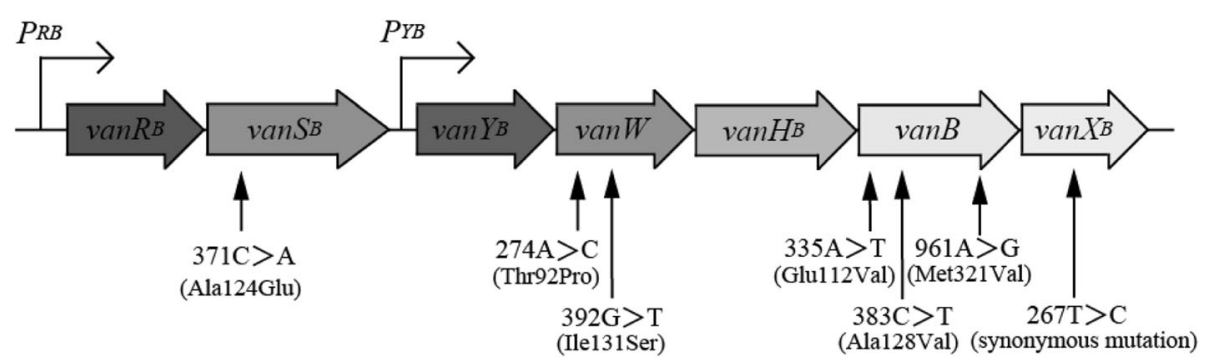

Fig. 1 Schematic representation of the vanB gene cluster and single nucleotide variations in $\mathrm{M} 1$ and $\mathrm{Y} 7$ compared with the van $B$ gene cluster in $B M 4661$. Expression of the $v a n B$ cluster genes is regulated by the two-component regulatory system of $V_{a n} S_{B} / V_{a n} R_{B}$. In the presence of $V A N$, the histidine kinase $V_{a n S_{B}}$ senses VAN and activates the transcriptional activator Van $R_{B}$. Consequently, the two-component regulatory genes (van $R_{B}$ and $\left.v_{a n S_{B}}\right)$ and the resistance genes $\left(\operatorname{vanY}_{B_{1}} v a n W, v_{a n H_{B}}\right.$ vanB and $\left.v a n X_{B}\right)$ are transcribed from the $V_{a n R_{B}}$-driven promoters $P R_{B}$ and $P Y_{B}$, respectively, to mediate the VAN resistance [8]. The arrows indicate the location of nucleotide variations (and resulting amino acid substitutions) identified in the vanB gene cluster of M1/Y7 compared with that of BM4661 
Table 1 Bacterial strains used in this study

\begin{tabular}{|c|c|c|c|c|c|c|c|c|c|c|c|c|c|c|c|c|c|}
\hline \multirow{2}{*}{$\begin{array}{l}\text { Strain/ } \\
\text { plasmid }\end{array}$} & \multirow[t]{2}{*}{ Species } & \multirow[t]{2}{*}{ Source } & \multirow{2}{*}{$\begin{array}{l}\text { Date of } \\
\text { Isolation } \\
\text { (mo/yr) }\end{array}$} & \multirow[t]{2}{*}{ Hospital } & \multirow{2}{*}{$\begin{array}{l}\text { VRE } \\
\text { genotype }\end{array}$} & \multirow{2}{*}{$\begin{array}{l}\text { Multilocus } \\
\text { sequence } \\
\text { typing }\end{array}$} & \multirow{2}{*}{$\begin{array}{l}\text { PFGE } \\
\text { types }\end{array}$} & \multicolumn{10}{|c|}{$\mathrm{MIC}(\mathrm{mg} / \mathrm{L})^{a}$} \\
\hline & & & & & & & & VAN & TEC & AMP & GEN & KAN & STR & $\mathrm{CHL}$ & TET & ERY & CIP \\
\hline M1 & E. faecium & feces & 09/09 & A & VanB & ST78 & $\mathrm{I}-\mathrm{C}$ & 3 & 1 & 256 & $>1024$ & $>1024$ & 32 & 8 & 64 & $>256$ & 64 \\
\hline M2 & E. faecium & feces & $10 / 09$ & A & $\operatorname{Van} B$ & ST78 & I-C & 3 & 1 & 256 & $>1024$ & $>1024$ & 32 & 8 & 64 & $>256$ & 64 \\
\hline M3 & E. faecium & feces & $10 / 09$ & $A$ & VanB & ST78 & I-A & 3 & 1 & 256 & $>1024$ & $>1024$ & 32 & 8 & 64 & $>256$ & 32 \\
\hline M4 & E. faecium & feces & $10 / 09$ & A & VanB & ST78 & I-B & 3 & 1 & 256 & 8 & $>1024$ & 32 & 8 & 64 & $>256$ & 64 \\
\hline M5 & E. faecium & feces & 10/09 & A & VanB & ST78 & III & 3 & 1 & 128 & 8 & 128 & 256 & 8 & 64 & $>256$ & 64 \\
\hline M6 & E. faecium & feces & $10 / 09$ & A & $\operatorname{Van} B$ & ST78 & $\|$ & 3 & 1 & 256 & 8 & $>1024$ & 32 & 8 & 64 & $>256$ & 64 \\
\hline M7 & E. faecium & feces & 10/09 & A & VanB & ST78 & I-C & 3 & 1 & 256 & $>1024$ & $>1024$ & 32 & 8 & 64 & $>256$ & 64 \\
\hline M8 & E. faecium & feces & $10 / 09$ & A & $\operatorname{VanB}$ & ST78 & I-A & 3 & 1 & 256 & $>1024$ & $>1024$ & 32 & 8 & 64 & $>256$ & 64 \\
\hline M9 & E. faecium & feces & 10/09 & A & VanB & ST78 & III & 3 & 1 & 128 & 8 & 128 & 256 & 8 & 64 & $>256$ & 64 \\
\hline M10 & E. faecium & feces & 0/09 & A & VanB & ST78 & I-A & 3 & 1 & 256 & $>1024$ & $>102$ & 32 & 8 & 64 & $>256$ & 64 \\
\hline Y7 & E. faecium & feces & $02 / 10$ & B & VanB & ST78 & $\|$ & 3 & 1 & 256 & $>1024$ & $>1024$ & 32 & 8 & 64 & $>256$ & 64 \\
\hline Y8 & E. faecium & feces & $02 / 10$ & B & VanB & ST78 & $\|$ & 3 & 1 & 256 & $>1024$ & $>1024$ & 32 & 8 & 64 & $>256$ & 64 \\
\hline Y9 & E. faecium & feces & $02 / 10$ & B & VanB & ST78 & $\|$ & 3 & 1 & 256 & $>1024$ & $>1024$ & 32 & 8 & 64 & $>256$ & 64 \\
\hline Y10 & E. faecium & feces & $02 / 10$ & B & VanB & ST78 & $\|$ & 3 & 1 & 256 & $>1024$ & $>1024$ & 32 & 8 & 64 & $>256$ & 64 \\
\hline Y11 & E. faecium & feces & $02 / 10$ & B & VanB & ST78 & $\|$ & 3 & 1 & 256 & $>1024$ & $>1024$ & 32 & 8 & 64 & $>256$ & 64 \\
\hline Y12 & E. faecium & feces & $02 / 10$ & B & VanB & ST78 & $\|$ & 3 & 1 & 128 & $>1024$ & $>1024$ & 32 & 8 & 64 & $>256$ & 64 \\
\hline Y13 & E. faecium & feces & $03 / 10$ & B & VanB & ST78 & $\|$ & 3 & 1 & 256 & $>1024$ & $>1024$ & 32 & 8 & 64 & $>256$ & 64 \\
\hline Y14 & E. faecium & feces & $03 / 10$ & B & VanB & ST78 & $\|$ & 3 & 1 & 256 & $>1024$ & $>1024$ & 32 & 8 & 64 & $>256$ & 64 \\
\hline Y15 & E. faecium & feces & 03/10 & B & VanB & ST78 & $\|$ & 3 & 1 & 256 & $>1024$ & $>1024$ & 32 & 8 & 64 & $>256$ & 64 \\
\hline FA2-2 & E. faecalis & - & - & - & - & - & - & 1 & 1 & 2 & 32 & 128 & 64 & 8 & 2 & 0.5 & 1 \\
\hline $\begin{array}{l}\text { FA2-2/ } \\
\text { pMG2200 }\end{array}$ & E. faecalis & - & - & - & VanB & - & - & 64 & 1 & 2 & 32 & 128 & 64 & 8 & 2 & 0.5 & 1 \\
\hline $\mathrm{M} 1 \mathrm{TC} C^{b}$ & E. faecalis & - & - & - & VanB & - & - & 3 & 1 & 2 & $>1024$ & $>1024$ & 64 & 8 & 64 & 0.5 & 1 \\
\hline Y1TC ${ }^{b}$ & E. faecalis & - & - & - & VanB & - & - & 3 & 1 & 2 & $>1024$ & $>1024$ & 64 & 8 & 64 & 0.5 & 1 \\
\hline BM4105RF & E. faecium & - & - & - & - & - & - & 1 & 1 & 3 & 8 & $>1024$ & 32 & 2 & 1 & 0.5 & 2 \\
\hline${\mathrm{M} 1 \mathrm{TC} 2^{c}}^{c}$ & E. faecium & - & - & - & VanB & - & - & 3 & 1 & 3 & $>1024$ & $>1024$ & 32 & 2 & 128 & 0.5 & 2 \\
\hline Y7TC2 ${ }^{c}$ & E. faecium & - & - & - & VanB & - & - & 3 & 1 & 3 & $>1024$ & $>1024$ & 32 & 2 & 128 & 0.5 & 2 \\
\hline
\end{tabular}

${ }^{a}$ VAN, vancomycin; TEC, teicoplanin; AMP, ampicillin; GEN, gentamicin; KAN, kanamycin; STR, streptomycin; CHL, chloramphenicol; TET, tetracycline; ERY, erythromycin; CIP, ciprofloxacin. ${ }^{b}$ Corresponding transconjugants of FA2-2 obtained by filter mating with the donor M1 or $\mathrm{Y} 7$ strain, respectively. ${ }^{c}$ Corresponding transconjugants of BM4105RF obtained by filter mating with the donor M1 or Y7 strain, respectively

sequences of the $v a n B$ gene clusters of M1 and Y7 with that of VanB-type E. faecium BM4661, which shows a high-level resistance to VAN $(\mathrm{MIC}=256 \mathrm{mg} / \mathrm{L})$ [17]. Compared with the $v a n B$ gene cluster of BM4661, M1 and $\mathrm{Y} 7 \mathrm{had}$ the same nucleotide variations leading to six amino acid substitutions in the $v a n B$ gene cluster (Fig. 1, Table 2). Similarly, we compared the sequences of these isolates with those of other VanB-type VRE in the NCBI database displaying MIC-values of VAN greater than 16 $\mathrm{mg} / \mathrm{L}$ [16-21]. Despite various levels of resistance to VAN, those strains showed high sequence identities in the $v a n B$ gene cluster (Additional file 1: Table S1). However, a total of three unique substitutions in $\operatorname{VanS}_{B}$ (Ala124Glu), VanW (Thr92Pro) and VanB (Ala128Val) were detected in M1 and Y7 (Fig. 1, Table 2, Additional files 2, 3 and 4: Figures S1-3).

\section{The vanB gene cluster of $\mathrm{M} 1$ or $\mathrm{Y} 7$ is mobilized to $E$.} faecalis and E. faecium

To test the effect of the host genetic background on the VAN resistance, conjugative transfer experiments of the $v a n B$ gene cluster were carried out. The $\operatorname{vanB}$ gene cluster of M1 or Y7 was not transferred by broth mating (data not shown), but was successfully transferred by filter mating to the recipient strain E. faecalis FA2-2 together with gentamicin, kanamycin and tetracycline resistances, and to E. faecium BM4105RF together with gentamicin and tetracycline resistances (Table 1). The resistance gene against kanamycin was expected to be co-transferred to BM4105RF. However, we could not detect this because BM4105RF is intrinsically resistant to kanamycin. The $v a n B$ gene clusters of $\mathrm{M} 1$ and $\mathrm{Y} 7$ transferred at frequencies of around $10^{-6}$ to $10^{-7}$ per donor cell to FA2-2, and 


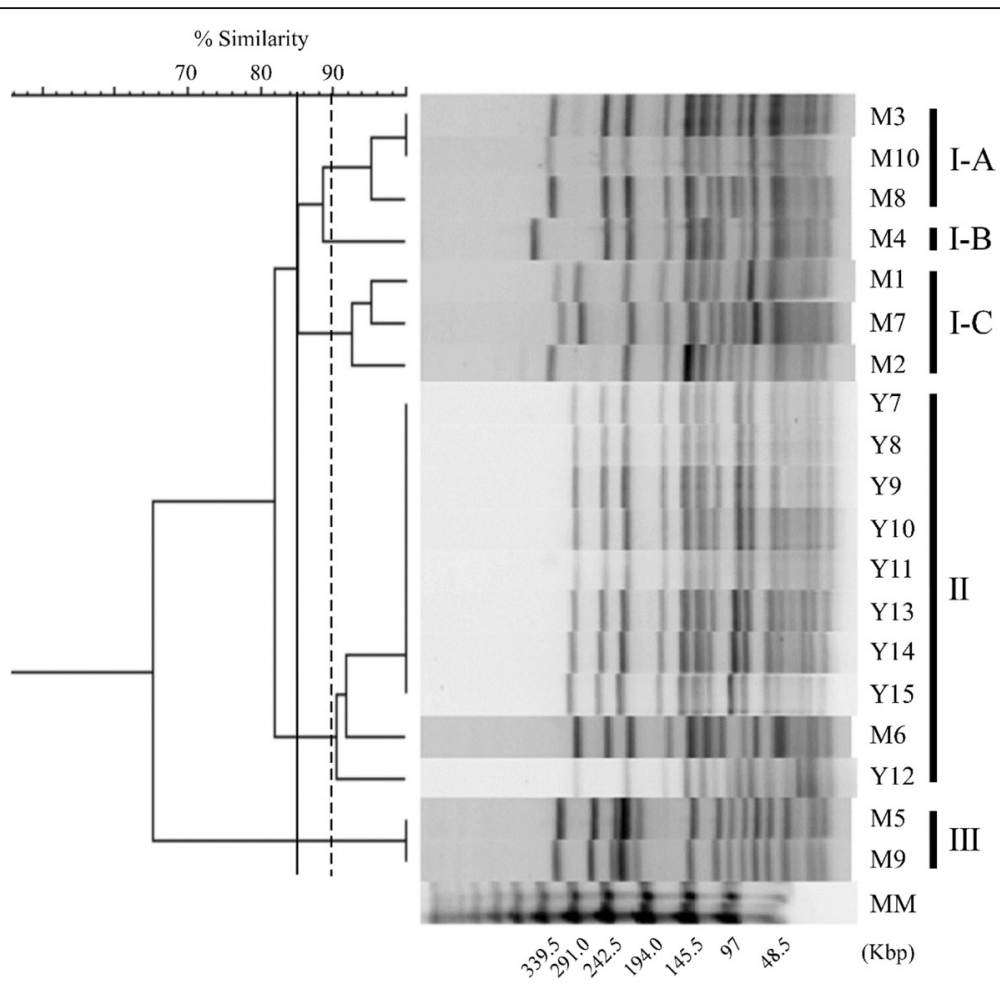

Fig. 2 PFGE profiles and dendrogram of the VAN susceptible VanB-type E. faecium isolates. Bacterial DNAs were digested with Smal and separated by pulsed-field gel electrophoresis (PFGE). The genetic relatedness was analyzed using the Dice coefficient and the dendrogram was constructed with the clustering algorithm of Unweighted Pair-Group Method with an Arithmetic Mean (UPGMA) using FP Quest Software (Bio-Rad). The optimization and the tolerance were 1 and 1.5\%, respectively. Major clusters and subclusters of the isolates were delineated with 85 and 90\% similarity cutoff values for PFGE as indicated by the vertical solid line and dotted line, respectively. A lambda PFG Ladder (New England BioLabs, MA) was used as the Molecular Marker (MM)

around $10^{-7}$ to $10^{-8}$ per donor cell to BM4105RF by filter mating. We identified the nucleotide sequences of the $v a n B$ gene clusters of the representative transconjugants (recipient; FA2-2), designated as M1TC (donor; M1) or Y7TC (donor; Y7). It was confirmed that the sequence of

Table 2 Single nucleotide variations found in the vanB. gene cluster of E. faecium $\mathrm{M} 1$ and $\mathrm{Y} 7$

\begin{tabular}{|c|c|c|}
\hline \multirow[t]{2}{*}{ Gene } & \multicolumn{2}{|l|}{ Substitutions $^{b}$} \\
\hline & $\mathrm{BM} 4661^{a}>\mathrm{M} 1 / \mathrm{Y} 7$ & \\
\hline $\operatorname{vanS}_{B}$ & $371 C>A$ & $($ Ala124Glu) \\
\hline vanW & $274 A>C$ & $(\text { Thr92Pro })^{d}$ \\
\hline vanW & $392 G>T$ & (lle131Ser) \\
\hline $\operatorname{van} B$ & $335 \mathrm{~A}>\mathrm{T}$ & (Glu112Val) \\
\hline $\operatorname{van} B$ & $383 C>T$ & $(\text { Ala128Val) })^{d}$ \\
\hline $\operatorname{van} B$ & $961 A>G$ & (Met321Val) \\
\hline $\operatorname{van} X_{B}$ & $267 \mathrm{~T}>\mathrm{C}$ & $S M^{c}$ \\
\hline
\end{tabular}

${ }^{a}$ The genetic information for BM4661 (accession no.; FJ767776.1) was obtained from the genome database in NCBI (http://www.ncbi.nlm.nih.gov/). ${ }^{b}$ The nucleotide sequences of $\operatorname{van} B$ gene clusters of $\mathrm{M} 1$ and $\mathrm{Y} 7$ strains were identical. The brackets indicate amino acid substitutions in van $B$ gene clusters. The numbers of substitutions represent the location of each gene and protein. ${ }^{\mathrm{S}} \mathrm{SM}$, synonymous mutation. ${ }^{d}$ Unique substitutions for $\mathrm{M} 1$ and $\mathrm{Y} 7$ strains (Additional file 2-4: Figures S1-3) the $v a n B$ gene clusters in M1TC or Y7TC and that of the respective donor strain were identical. The transconjugants showed low MIC values for VAN and TEC as well as the donor strain (Table 1), indicating that neither the $v a n B$ gene cluster from M1 nor Y7 confers the glycopeptide resistance to the FA2-2 and the BM4105RF strains or to the original E. faecium host.

\section{The van B gene cluster of $\mathrm{M} 1$ or $\mathrm{Y} 7$ is located on a plasmid and transferred to a chromosome of the recipient}

To determine the localization of the $\operatorname{van} B$ gene cluster in these strains, we performed Southern transfer and a hybridization analysis. Southern hybridization of the $\operatorname{vanB}$ gene probe to the ca. $330 \mathrm{~kb}$ and ca. $100 \mathrm{~kb} \mathrm{S1}$ nucleasetreated DNAs of M1 and Y7 indicated that $v a n B$ gene cluster located on a plasmid (Additional file 5: Figure S4). However, co-hybridization with the $\operatorname{vanB}$ gene probe and 23S rRNA gene probe to I-CeuI-digested DNAs were identified in M1TC and Y7TC (Additional file 6: Figure S5). Furthermore, we could not confirm the transfer of the original plasmid to M1TC or Y7TC by Southern hybridization analysis (Additional file 5: Figure S4). These results strongly suggested that the mobile elements including the $\operatorname{van} B$ gene cluster were inserted into the chromosomes of the transconjugants. 
Reversion of the low-level VAN resistance of vanB gene cluster to the higher-level VAN resistance

To test whether the $v a n B$ gene cluster in M1 and Y7 was able to revert VAN susceptible phenotype to VAN resistant phenotype, we performed reversion experiments. Zero point one milliliter of each $24 \mathrm{~h}$ culture of M1, Y7, M1TC and Y7TC strains without drug was plated onto a THB agar plate containing VAN at concentration of $16 \mathrm{mg} / \mathrm{L}$, incubated at $37^{\circ} \mathrm{C}$. Spontaneous VAN-resistant mutants were obtained with a frequency of $10^{-6}-10^{-7} /$ cell (Table 3). We defined one spontaneous VAN-resistant derivative mutant as a revertant. The frequencies of reversion in the transconjugants M1TC and Y7TC were almost as same as those of M1 and Y7. To examine the genetic changes in the $\operatorname{van} B$ gene cluster, we first checked the nucleotide sequence of the $\operatorname{van} B$ gene cluster of the 14 revertants derived from M1TC or Y7TC, transconjugants from mating with FA2-2 as a recipient. Ten revertants derived from M1TC and four from Y7TC were designated as M1TCR1-M1TCR10 and Y7TCR1-Y7TCR4, respectively. The mutations found in the $v a n B$ gene cluster in these revertants were concentrated in the intracytoplasmic domain of $\mathrm{VanS}_{\mathrm{B}}$ (Fig. 3, Table 4). Four out of ten revertants from M1TC (40\%) and three out of four from Y7TC (75\%) had mutations in the $v a n S_{B}$ gene. All revertants showed higher MIC values for VAN (MIC>16 mg/L). Among them, M1TCR6 was the only strain showing both the VAN and TEC resistant phenotype. This revertant had an insertion of $21 \mathrm{bp}$ (7 a. a.) in the intracytoplasmic domain of VanS $_{\mathrm{B}}$ (Fig. 3, Table 4). Furthermore, in two revertants, M1TCR2 and Y7TCR4, mutations were identified in $v a n B$ gene. We also examined the sequences of the intracytoplasmic domain of the $\operatorname{vanS}_{B}$ gene in the 24 revertants derived from M1 and Y7 (M1R1-M1R17 and Y7R1-Y7R7). Of these revertants, 17 revertants (71\%) had mutations in the intracytoplasmic domain of $\mathrm{VanS}_{\mathrm{B}}$ (Fig. 3, Additional file 7: Table S2). We could not obtain revertants with mutations in the $v a n R_{B}$, $v a n W_{B}, v a n H_{B}$ or the $\operatorname{van} X_{B}$ genes. The $v a n S_{B}$ gene encodes the sensor protein of the two-component regulatory system regulating transcription levels of the $\operatorname{van} B$ gene clusters. This result suggested that the VAN resistant phenotype was caused by a change in the transcription level of the $\operatorname{van} B$ gene cluster.

Table 3 Frequency of reversion to VAN-resistant phenotype

\begin{tabular}{ll}
\hline Parent strain & The frequency of reversion $^{a}$ \\
\hline M1 & $(4.2 \pm 2.0) \times 10^{-7}$ \\
Y7 & $(1.7 \pm 1.2) \times 10^{-6}$ \\
M1TC $^{b}$ & $(2.4 \pm 0.5) \times 10^{-7}$ \\
Y7TC $^{b}$ & $(3.5 \pm 1.0) \times 10^{-7}$ \\
\hline
\end{tabular}

${ }^{a}$ Frequency was estimated from the colony-forming unit (CFU) ratio of resistant strains to total strains. ${ }^{b}$ Corresponding transconjugants of $\mathrm{M} 1$ or Y7 strain
Increased expression level of the vanB gene cluster in the revertants

The transcription of the $v a n B$ gene cluster is strictly suppressed in the absence of VAN, and induction of transcription by VAN via the $\operatorname{Van} S_{B} / R_{B}$ pathway is essential for mediating VAN resistance [7]. To test whether the increased VAN resistance was due to the increase of transcription in $v a n B$ gene cluster, we examined the transcription level of $\operatorname{van} X_{B}$ gene as a representative of the $v a n B$ gene cluster by real-time PCR (Table 4). In the absence of VAN, transcription of $\operatorname{van} X_{B}$ was not detected in all strains except M1TCR6. In the presence of VAN, there was an approximately 4-fold increase in M1TCR1, M1TCR2 and M1TCR5 compared with that in a parent strain M1TC. There was ca. 6-fold increase in M1TCR3 and ca. 40-fold increase in M1TCR6 compared with that in M1TC. Additionally, the transcription of $\operatorname{van} X_{B}$ gene in M1TCR6 was detected even in the absence of VAN (Table 4). These data suggested that the increased expression levels of the $\operatorname{vanB}$ gene cluster were associated with the increased VAN resistance of the revertants, although no mutation was identified in $v a n B$ gene cluster in M1TCR1 and M1TCR5.

\section{Acquisition of the vanB gene cluster did not have effect on the growths of transconjugants and revertants}

The drug resistant determinants impose a burden on cell growth, and the biological cost for expressing the drug resistance is an important factor for their prevalence in host human tissue or any clinical setting $[22,23]$. To examine the effect of the $v a n B$ gene clusters with various level of VAN resistances on bacterial growth, FA2-2, FA2-2/pMG2200, M1TC, M1TCR3 and M1TCR6 were individually incubated at $37^{\circ} \mathrm{C}$ in THB and their growth curves were analyzed (Fig. 4). Individual growth curves were similar to each other, except for M1TCR6 in the absence of VAN. Similarly, growth speed of M1TCR6 was lower than those of other VanB-type enterococci in the presence of VAN. These results indicated that the acquisition of the mobile element including the $v a n B$ gene cluster did not suppress bacterial growth in vitro, if its gene expression was inducible (and not constitutive).

\section{Targeted mutagensis of vanB gene cluster restored the resistance to VAN}

To examine whether single nucleotide variations (Fig. 1, Table 2) in the $v a n B$ gene clusters are responsible for the attenuated VAN resistance (in M1 and M7), we carried out targeted mutagenesis by homologous recombination with the mutated genes using a recombinant plasmid pCJK47.

Three unique substitutions, in $\operatorname{VanS}_{\mathrm{B}}(371 \mathrm{C}>\mathrm{A}$; Ala124Glu), VanW (274A > C; Thr92Pro) and VanB (383C > T; Ala128Val), were detected in M1 and Y7 (Table 2). We exchanged these three unique nucleotide variations to those 


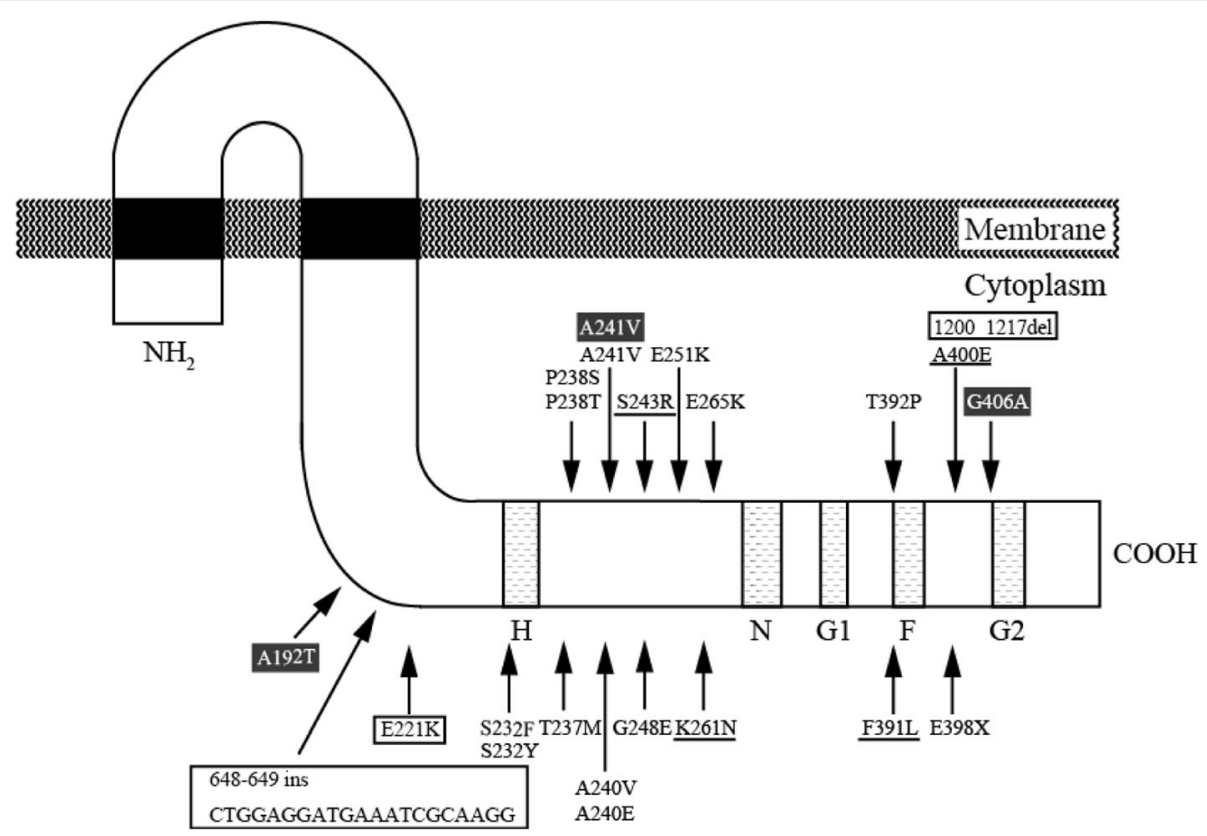

Fig. 3 Schematic representation of novel mutations in the $\operatorname{vanS}_{B}$ gene of the revertants. VanS $S_{B}$ contains the motifs designated as $H, N, G 1, F, G 2$ (lightly shaded boxes) that are the conserved motifs of histidine protein kinases [44]. The His residue (233) in the H box is the primary autophosphorylation site [29].The arrows and characters in black boxes represent mutations found in M1R, the underlined characters represent those in Y7R, those in boxes represent mutations in M1TCR and characters by themselves represent mutations in YTTCR, respectively

Table 4 Glycopeptide MICs and detected mutations in vanB gene cluster of the VAN-resistant revertants

\begin{tabular}{|c|c|c|c|c|c|c|}
\hline \multirow[t]{2}{*}{ Strain } & \multicolumn{2}{|l|}{ Mutation $^{a}$} & \multicolumn{2}{|c|}{$\mathrm{MIC}(\mathrm{mg} / \mathrm{L})^{b}$} & \multicolumn{2}{|c|}{ RT-PCR (Fold change $( \pm S E)^{c}$} \\
\hline & $\operatorname{vanS}_{B}$ gene & vanB gene & VAN & TEC & VAN (-) & $\operatorname{VAN}(+)$ \\
\hline M1TC & - & - & 3 & 1 & N. D. & 1 \\
\hline M1TCR1 & N. D. & N. D. & 16 & 1 & N. D. & $4.4( \pm 1.0)$ \\
\hline M1TCR2 & N. D. & 574G > A(Ala192Thr) & 16 & 1 & N. D. & $3.6( \pm 0.5)$ \\
\hline M1TCR3 & 661G > A(Glu221Lys) & N. D. & 16 & 1 & N. D. & $5.8( \pm 1.2)$ \\
\hline M1TCR4 & N. D. & N. D. & 16 & 1 & - & - \\
\hline M1TCR5 & N. D. & N. D. & 16 & 1 & N. D. & $4.9( \pm 1.4)$ \\
\hline M1TCR6 & $\begin{array}{l}\text { 648-649 ins CTGGAGGATGAAA } \\
\text { TCGCAAGG }\end{array}$ & N. D. & 128 & 128 & $36.1( \pm 8.0)$ & $39.5( \pm 13.9)$ \\
\hline M1TCR7 & 1200-1217 del & N. D. & 16 & 1 & - & - \\
\hline M1TCR8 & N. D. & N. D. & 16 & 1 & - & - \\
\hline M1TCR9 & N. D. & N. D. & 16 & 1 & - & - \\
\hline M1TCR10 & 661G > A(Glu221Lys) & N. D. & 32 & 1 & - & - \\
\hline Y7TC & - & - & 3 & 1 & & \\
\hline Y7TCR1 & 722C > T(Ala241Val) & N. D. & 16 & 1 & - & - \\
\hline Y7TCR2 & N. D. & N. D. & 16 & 1 & - & - \\
\hline Y7TCR3 & 574G > A(Ala192Thr) & N. D. & 64 & 1 & - & - \\
\hline Y7TCR4 & 1218G > C(Gly406Ala) & 317C > A(Ala106Glu) & 16 & 1 & - & - \\
\hline
\end{tabular}

${ }^{a}$ The sequence was compared with the vanB gene cluster of the cognate parent strain, M1TC or Y7TC. ${ }^{b}$ VAN: vancomycin, TEC: teicoplanin. ${ }^{c}$ Real-time PCR data represent the fold changes in $\operatorname{van}_{B}$ transcriptional level relative to that of M1TC in the presence of vancomycin (1 mg/L; VAN (+)). The values were the means of three independent experiments with standard error, each experiment performed in duplicate. N. D.; not detected 


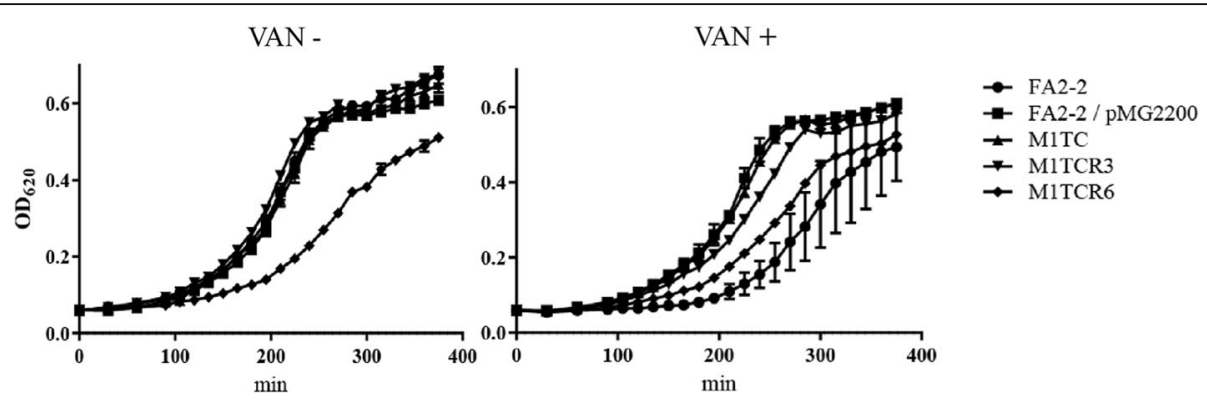

Fig. 4 Growth curves of the recipient, transconjugant and revertants in the presence or absence of VAN. Overnight bacterial cultures were diluted 100-fold in fresh THB broth with (Right) or without (Left) $1 \mathrm{mg} / \mathrm{L} \mathrm{VAN}$. The culture was incubated at $37^{\circ} \mathrm{C}$ and the turbidity was measured at an optical density of $620 \mathrm{~nm}\left(\mathrm{OD}_{620}\right)$ at each time point. The values were the mean of three independent experiments with standard error, each experiment was performed in triplicate

of VanB-type VRE displaying MIC values of VAN greater than $16 \mathrm{mg} / \mathrm{L}$ (Table 2, Additional file 2-4: Figures S1-3). The mutant strain with VanW $(274 \mathrm{C}>\mathrm{A}$; Pro92Thr) and/ or VanB (383 T > C; Val128Ala) did not show increased VAN resistance $(\mathrm{MIC}=3 \mathrm{mg} / \mathrm{L})$. However, the MIC values of VAN in the mutants with $\operatorname{VanS}_{\mathrm{B}}(371 \mathrm{~A}>\mathrm{C}$; Glu124Ala) and VanW (274C > A; Pro92Thr) or VanB $(383 \mathrm{~T}>\mathrm{C}$; Val128Ala) were increased (MIC $=8 \mathrm{mg} / \mathrm{L}$ ). Exchanges of all these three nucleotides in M1TC restored the MIC value of VAN up to $16 \mathrm{mg} / \mathrm{L}$ (Table 5). In particular, $\mathrm{VanS}_{\mathrm{B}}$ (371A > C; Glu124Ala) appeared to be the key substitution required for restoration of VAN resistance (Table 5).

\section{Discussion}

\section{Epidemiology of M1-M10 and Y7-Y12 E. faecium strains}

In this study, we genetically characterized the E. faecium isolates M1-M10 and Y7-Y15 strains, which were susceptible to VAN despite possessing the $\operatorname{vanB}$ gene cluster (Table 1). These strains were isolated from two unrelated hospitals, but showed similar genetic backgrounds belonging to ST78 (Fig. 2, Table 1). The ST78 is

Table 5 Glycopeptide MICs of the MITC derivatives that had been introduced mutations in vanB gene cluster

\begin{tabular}{|c|c|c|}
\hline \multirow[t]{2}{*}{ Strain } & \multicolumn{2}{|c|}{$\mathrm{MIC}(\mathrm{mg} / \mathrm{L})^{a}$} \\
\hline & VAN & TEC \\
\hline M1TC & 3 & 1 \\
\hline M1TC $\operatorname{vanS}_{B} E_{-} 124 A^{b}$ & 4 & 1 \\
\hline M1TC vanB_ V128A & 3 & 1 \\
\hline M1TC vanW_P92T ${ }^{b}$ & 3 & 1 \\
\hline M1TC vanS $_{B_{-}}$E124A/vanB_V128A $\mathrm{A}^{b}$ & 8 & 1 \\
\hline M1TC vanS $B_{-}$E124A/vanW_P92T & 8 & 1 \\
\hline M1TC vanB_V128A/vanW_P92T ${ }^{b}$ & 3 & 1 \\
\hline M1TC vanS $_{B_{-}}$E124A/vanB_V128A/vanW_P92T ${ }^{b}$ & 16 & 1 \\
\hline
\end{tabular}

${ }^{a}$ VAN, vancomycin; TEC, teicoplanin ${ }^{b}$ Three unique substitutions for M1 and Y7 255 strains were exchanged to that of the reference gene of pMG2200 by $\mathrm{pCJK} 47$-used 256 homologous recombination one of the important groups which is associated with hospitalized patients and belongs to Bayesian analysis of population structure (BAPS) $2-1$. The BAPS $2-1$ is a hospital-adapted lineage [24]. The PFGE patterns of the Y7-Y15 strains were highly related, suggesting the clonal dissemination of these isolates in Hospital B. Meanwhile, M1-M10 strains showed a relatively small genetic variation in their PFGE pattern, and the PFGE of M5 and M9 (cluster III) showed 65\% similarities with those of the other $\mathrm{M}$-series strains. The recombination occurs more frequently and has an important role in a genetic diversity in E. faecium [24, 25]. During a long term surveillance, it was reported that de novo generation of vancomycin-resistant $E$. faecium by mobile element including $v a n B$ gene cluster was frequent [26]. Taken together with the fact that M1-M10 and Y7-Y15 strains shared an completely identical $v a n B$ gene cluster and similar antimicrobial susceptibility profile, there seemed to be a possibility of a horizontal gene transfer and/or a long-term colonization sufficient for genetic rearrangement in Hospital A and a transmission between patients in Hospital B.

\section{Stealth behavior of potential VAN resistant enterococci}

About a hundred cases of VRE infection are reported in Japan annually by National Institute of Infectious Disease (NIID) surveillance but there are few investigations of the prevalence of VRE (http://www.nih.go.jp/niid/ja/). Matsushima et al. reported the regional spread of VRE in Kyoto prefecture [27]. However, because of the VAN-concentration used for the VRE screening $(15 \mathrm{mg} / \mathrm{L})$, it is likely that they failed to detect VAN susceptible VanB-type enterococci [27]. Under the Infectious Disease Control Law in Japan (Kansenshō-Hō, Act on Prevention of Infectious Disease and Medical Care for Patients Suffering Infectious Disease of Japan), notifiable VRE is defined as enterococcal clinical isolates causing infectious disease and showing VAN MIC $\geq 16 \mathrm{mg} / \mathrm{L}$. On the other 
hand, MIC clinical breakpoints for Enterococci defined by Clinical and Laboratory Standards Institutes (CLSI) are as follows, for vancomycin $(\mathrm{mg} / \mathrm{L})$, susceptible, $\leq 4$; intermediate, 8-16; resistant, $\geq 32$ (http://clsi.org/). The E. faecium isolates we reported here showed VAN susceptible phenotype $(\mathrm{MIC}=3 \mathrm{mg} / \mathrm{L})$ and they are not notifiable VRE in Japan (Table 1). In addition, we also demonstrated the spontaneous reversion of the VAN susceptible vanB-carrying E. faecium from VAN susceptible phenotype to VAN resistant phenotype. These revertants, displaying MIC values of VAN greater than $16 \mathrm{mg} / \mathrm{L}$, were considered intermediate or resistant by CLSI definition. European Committee on Antimicrobial Susceptibility Testing for enterococci (EUCAST) defined vancomycin resistant, $>4 \mathrm{mg} / \mathrm{L}$. In either case, vancomycin treatment might not be effective against these revertants. This spontaneous reversion occurred with a frequency of $10^{-6}-10^{-7}$ /parent cell (Table 3 ). This frequency seems to be relatively high in comparison with that of spontaneous antibiotic-resistant mutants in other bacteria [28]. These barely detectable VAN susceptible strains have the capacity for long-term colonization in the human gut without producing any symptoms, because this $v a n B$ gene cluster does not affect bacterial fitness in the absence of VAN (Fig. 4). Consistent with our results, Marie-Laure Foucault et al. has reported that inactivated or inducible Tn1549 carrying the $v a n B$ gene cluster produces no additional fitness cost [23]. Furthermore, the transfer of this $\operatorname{van} B$ gene cluster from the plasmid residing in $\mathrm{M} 1$ or $\mathrm{Y} 7$ to the chromosome of other enterococcal cell indicated the risk of efficient dissemination of VAN resistance genes. Therefore, it should be considered that "stealth behavior" of this $v a n B$ gene cluster should be subjected to the active surveillance by the standard VAN screening method in clinical settings.

\section{Genetic mutations leading to the reversion phenotype}

It has been reported elsewhere that enterococcus strains harboring the VanB-type VAN resistance gene cluster showed various MIC level for VAN or TEC [6, 7]. However, the determinants involved in this variation of MIC are not well understood [9]. We showed the experimental reversion to increased VAN resistance by targeted mutagenesis in $\mathrm{M} 1$ and $\mathrm{Y} 7$ strains, and in their corresponding transconjugants M1TC and Y7TC (Tables 1, 3). The reversion to the increased VAN resistance appeared to be resulted from the increased expression level of the $\operatorname{van} B$ gene cluster (Table 4). It was previously reported that various mutations in the vanS $S_{B}$ gene changed the glycopeptide resistance phenotype $[4,7,29]$. Consistent with this, 24 strains of the 38 revertants (63\%) that were tested carried the novel mutations in intracytoplasmic domain of $v a n S_{B}$ gene (Fig. 3, Table 4 and Additional file 7: Table S2). In general, the high frequency of reverting to antibiotics resistance and the concentration of mutations in "one gene" indicated that the mechanism of reversion was loss of function of the gene rather than gain of function [28]. These mutations appeared to lead to the attenuated phosphatase function of $\operatorname{VanS}_{\mathrm{B}}$. Meanwhile, the rest of the revertants derived from M1TC or Y7TC did not have any mutation in the $v a n B$ gene cluster and the sensor domain

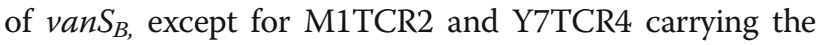
mutations in the $v a n B$ gene (Table 4). However, two revertants, M1TCR1 and M1TCR5 did not have mutation in van $B$ gene cluster, but still showed increased expression of the $v a n B$ gene cluster in the presence of VAN (Table 4), indicating that there must be mutation(s) outside of the $v a n B$ gene cluster affecting the transcription of $v a n B$ genes. Additionally, M1TCR2 had an amino acid substitution in the $v a n B$ gene (Table 4). According to previous reports, this amino acid substitution of VanB did not seem to be important for D-Ala-D-Lac ligase function [30-32]. Therefore, the responsible mutation for reversion of M1TCR2 could be outside of the cluster like that of M1TCR1 and M1TCR5. The possible cross talks between $V_{a n R}$ and cognate enterococcal kinase were presumed to be responsible in the previous study [33]. This report may provide clues about the mechanism of reversion without a mutation in the $v a n B$ gene cluster including the $P_{R B} / P_{Y B}$ promotor region. A further study is underway to clarify this point. Collectively, reversion from an attenuated VAN resistance mediated by this $v a n B$ gene cluster to an increased VAN resistance appears to be associated with the increased transcription of the $v a n B$ gene cluster, but the mutation or the mechanism responsible for the reversion appears to be varied and not limited in the $v a n B$-related genes.

\section{Single nucleotide variations in the vanB gene cluster attenuated resistance to VAN}

In addition to this revertant analysis, we carried out targeted mutagenesis to examine whether the single nucleotide substitutions (Table 2) in the $v a n B$ gene cluster of $\mathrm{M} 1$ and $\mathrm{Y} 7$ are responsible for the attenuated resistance to VAN. There were three unique amino acid substitutions (Ala124Glu in $\mathrm{VanS}_{\mathrm{B}}$, Thr92Pro in VanW and Ala128Val in VanB) in the M1/Y7 strain (Table 2). It was reported that the essential genes of VanB-type VAN resistance were $v a n H_{B}, v a n B$ and $\operatorname{van} X_{B}$ [1] and deletion of $v a n W_{B}$ in V583 did not affect the VAN resistance [34]. In addition, it has been reported previously that the amino acid substitution in VanB (Ala128Val) did not have an impact on ligase function [30-32]. However, our experiment suggested that three single nucleotide variations resulting in an amino acid change in the $v a n B$ gene cluster appeared to have a combined impact on vancomycin resistance (Table 5). The MIC-values of VAN in the mutant strains without $\operatorname{VanS}_{\mathrm{B}}(371 \mathrm{~A}>\mathrm{C}$; Glu124Ala) were 
equal to that in the parent strain $(\mathrm{MIC}=3 \mathrm{mg} / \mathrm{L})$. Therefore, the nucleotide sequence variation in $\operatorname{van}_{B}$ gene is assumed to be the key factor, but all of the three variations are needed for VAN susceptible phenotype.

\section{Conclusions}

It has been thought that VVE means only VanA-type VAN susceptible enterococci that can revert to the resistant phenotype [14]. As shown in this study, these VAN susceptible VanB-type isolates also have the ability to revert to the highly resistant phenotype to VAN. Due to the potential threat in clinical settings and the risk of treatment failure, these strains should be included in VVE. Further study is required to understand by what molecular mechanism(s) the stealthy $\operatorname{van} B$ gene cluster converts to the higher-level resistance and the responsible determinant(s) for the varied range of glycopeptide MIC in the VanB-type resistance enterococci.

\section{Methods}

Bacterial strains, plasmids, growth condition, oligonucleotides, media, and antimicrobial reagents

The bacterial strains and plasmids used in this study are shown in Table 1. E. faecium M1-M10 strains and Y7Y15 strains were provided by MIROKU Medical Laboratory Co. (Nagano, Japan) and Yamaguchi Prefectural Institute of Public Health and Environment, respectively. pMG2200 is the pheromone-responsive plasmid isolated from $E$. faecalis clinical isolates harboring the $v a n B$ gene cluster. pMG2200 conferred VAN resistance on the host strain, showing an MIC for VAN of more than $64 \mathrm{mg} / \mathrm{L}$ [16]. The oligonucleotides used in this study are shown in Additional file 8: Table. S3. Enterococcal strains were routinely grown in Todd-Hewitt broth (THB; Difco, Detroit, MI) at $37^{\circ} \mathrm{C}$. Escherichia coli strains were grown in Luria-Bertani (LB; Difco) at $37^{\circ} \mathrm{C}$. All antibiotics were obtained from Sigma Co. (St. Louis, MO).

\section{Antibiotic susceptibility test}

MICs were determined by the agar dilution method according to Clinical and Laboratory Standards Institutes (CLSI) guidelines (http://clsi.org/). After each strain was grown overnight in Mueller-Hinton broth (MHB; Nissui, Tokyo, Japan), the cultures were diluted 100-fold with fresh MHB. An inoculum of approximately $5 \times 10^{5}$ cells $(5 \mu \mathrm{l})$ was spotted onto a series of Mueller-Hinton agar (Eiken, Tokyo, Japan) plates containing a range of concentrations of the test drug. After incubation at $37^{\circ} \mathrm{C}$ for $24 \mathrm{~h}$, the susceptibility was determined. The interpretation of the results was in compliance with standards recommended by CLSI. The breakpoints of MICs for resistance to antibiotics were defined as follows $(\mathrm{mg} / \mathrm{L})$; vancomycin (VAN), $\geq 16$; teicoplanin (TEC), $\geq 16$; ampicillin (AMP), 212.5; gentamicin (GEN), > 500; kanamycin
(KAN), $\geq 1024$; streptomycin (STR), > 1000; chloramphenicol (CHL), $\geq 32$; tetracycline (TET), $\geq 16$; erythromycin (ERY), $\geq 8$; ciprofloxacin (CIP), $\geq 4$ (Table 1). E. faecalis V583 and ATCC29212 were used as controls.

\section{Pulsed-field gel electrophoresis (PFGE) analysis and dendrogram}

PFGE analysis was performed as previously described [35]. Briefly, enterococci DNA embedded in an agarose plug was digested overnight at $25^{\circ} \mathrm{C}$ using SmaI (Roche, Basel, Switzerland), and then subjected to PFGE using a CHEF-MAPPER (Bio-Rad, CA) according to the manufacture's protocol. The guidelines proposed by Tenover et al. were used for the interpretation of PFGE results [36]. The genetic relatedness was analyzed using the Dice coefficient and the dendrogram, and was calculated with the clustering algorithm of Unweighted Pair-Group Method with an Arithmetic Mean (UPGMA) using FP Quest Software (Bio-Rad) [37, 38]. A lambda PFG Ladder (New England BioLabs, MA) was used as the Molecular Marker (MM).

\section{Southern transfer and hybridization analysis}

PFGE analyses with S1 nuclease or I-CeuI were performed as described above. Briefly, enterococci DNA embedded in agarose plug was digested for $20 \mathrm{~min}$ at $37^{\circ} \mathrm{C}$ with $\mathrm{S} 1$ nuclease (Promega, WI) or overnight at $37^{\circ} \mathrm{C}$ with I-CeuI (New England BioLabs, MA), the DNAs were then subjected to PFGE using a CHEF-MAPPER (Bio-Rad, CA) according to the manufacture's protocol. Southern hybridization was performed with the digoxigenin-based non-radioisotope system of Boehringer GmbH (Mannheim, Germany), and Southern transfer and the hybridization procedure were carried out according to the manufactures' manual and standard protocol [39]. Specific probes for $v a n B$ gene and the 23S rRNA gene of E. faecium were made by PCR DIG Probe Synthesis kit (Roche) and specific primers for each gene [40].

\section{Multilocus sequence typing (MLST) analysis}

MLST was performed as previously described [41]. The house keeping genes atpA, $d d l, g d h, p u r K, g y d, p s t S$ and $a d k$ were sequenced and STs were determined according to MLST.net (http://efaecium.mlst.net/).

\section{Conjugation experiment}

Filter mating was performed as described previously [42]. Briefly, an overnight culture of the bacteria was diluted 50 -fold in $5 \mathrm{ml}$ of fresh THB broth and pre-cultured until the end of the exponential phase. One hundred microliter of the donor culture and $100 \mu \mathrm{l}$ of the recipient culture were mixed in $5 \mathrm{ml}$ of THB broth. FA2-2 or BM4105RF and wild $\mathrm{M} 1$ or $\mathrm{Y} 7$ were used as the recipients and donors, respectively. The mating mixture of donor and recipient 
was collected on a $0.45 \mu \mathrm{m}$ nitrocellulose membrane filter (Merck Millipore, Darmstadt, Germany), and incubated on THB agar plate at $37^{\circ} \mathrm{C}$ for $5 \mathrm{~h}$. The mating mixture was plated on selective THB agar containing rifampicin $25 \mathrm{mg} / \mathrm{L}$, fusidic acid $25 \mathrm{mg} / \mathrm{L}$ and VAN $3 \mathrm{mg} / \mathrm{L}$. After incubation at $37^{\circ} \mathrm{C}$ for $48 \mathrm{~h}$, the colonies that grew were isolated and purified at least twice. The frequency of conjugation was calculated as the number of transconjugants per donor cell.

\section{Isolation of the VAN-resistant revertants}

Cultures of each strain grown in THB broth at $37^{\circ} \mathrm{C}$ for $24 \mathrm{~h}$ were plated onto a THB agar plate with or without VAN at concentration of $16 \mathrm{mg} / \mathrm{L}$. Colonies grown after $24 \mathrm{~h}$ of incubation at $37^{\circ} \mathrm{C}$ were counted and the frequency of the rate of reversion was estimated from the colony-forming unit (CFU) ratio of resistant strains to total strains. The values were the average of three independent experiments with standard error. Colonies grown on THB agar plates with VAN $(16 \mathrm{mg} / \mathrm{L})$ were isolated on new THB agar plates containing VAN $(16 \mathrm{mg} / \mathrm{L})$. Single colonical isolations were performed at least twice for each strain. The MICs of the resulting revertants were determined by the agar dilution method as described above. The nucleotide sequences of the $v a n B$ gene cluster was determined as described above.

\section{qRT-PCR analysis}

An overnight bacterial culture was diluted 100-fold in brain heart infusion (BHI) medium with or without VAN $(1 \mathrm{mg} / \mathrm{L})$ and incubated at $37^{\circ} \mathrm{C}$ until exponential phase. After collection of the bacterial cells by centrifugation for $5 \mathrm{~min}$ at $12,000 \mathrm{rpm}$, total RNA was prepared using a Fast RNA Pro Red Kit (Q-Biogene, Inc) and Fast Prep disintegrator ( $40 \mathrm{~s}$, speed: 6.0 ). The resulting RNA was further extracted with chloroform, precipitated with ethanol and resuspended in $0.05 \mathrm{ml}$ diethylpyrocarbonate (DEPC)- treated water. Total RNA $(30 \mu \mathrm{g})$ was incubated with recombinant DNase I (RNase-free) and RNase inhibitor (Takara Bio Inc., Shiga, Japan) at $37^{\circ} \mathrm{C}$ for $30 \mathrm{~min}$. After extraction with phenol-chloroform-isoamyl alcohol (25:24:1) and chloroform-isoamyl alcohol (24:1), the samples were precipitated with ethanol and resuspended with $20 \mu \mathrm{l}$ of DEPC- treated water. The concentration of the RNA solution was determined by a fluorescence-based assay with Qubit 3.0 (Thermo Fisher Scientific Inc., MA). Reverse transcription was carried out with the PrimeScript RT Master Mix (Takara Bio Inc.). Real-time PCR was carried out with the Thunderbird SYBR qPCR Mix (Toyobo Co., Tokyo, Japan) using an ABI 7500 Fast RT-PCR instrument (ABI, CA). Real-time-PCR cycled at $1 \mathrm{~min}$ at $95^{\circ} \mathrm{C}$, followed by 40 cycles of $15 \mathrm{~s}$ at $95^{\circ} \mathrm{C}, 15 \mathrm{~s}$ at $55^{\circ} \mathrm{C}, 1 \mathrm{~min}$ at $72{ }^{\circ} \mathrm{C}$. The real-time PCR primers were designed by
Primer3Plus (http://www.bioinformatics.nl/cgi-bin/primer3plus/primer3plus.cgi) (Additional file 8: Table S3).

\section{Kinetics of cell growth}

Overnight bacterial cultures were diluted 100-fold in fresh THB broth with or without VAN $(1 \mathrm{mg} / \mathrm{L})$. The culture was incubated at $37^{\circ} \mathrm{C}$ and the turbidity was measured at an optical density of $620 \mathrm{~nm}$ at each time point using a Multiskan FC Microplate Photometer (Thermo Fisher Scientific Inc.).

\section{Plasmid construction and targeted mutagenesis of the vanB gene cluster}

Targeted mutagenesis of the $v a n S_{B}, \operatorname{van} B, \operatorname{van} W$ genes in the $\operatorname{van} B$ gene cluster was performed as previously described [43]. Briefly, the DNA fragments to be inserted were constructed by PCR using the corresponding primers, as indicated in Additional file 8: Table S3, and inserted into the pCJK47 vector using the restriction enzyme EcoRI (Roche) and a DNA Ligation Kit (Takara Bio Inc.), as described previously. After transformation into E. coli EC1000 as previously described elsewhere, the recombinant-expressing $E$. coli strains were incubated in $5 \mathrm{ml}$ of LB containing $300 \mathrm{mg} / \mathrm{L}$ erythromycin at $37^{\circ} \mathrm{C}$ with shaking. Recombinant plasmid DNA was extracted using the QIAprep Spin Miniprep Kit (QIAGEN, Hilden, Germany). The constructed plasmids were sequenced to confirm that the desired sequence had been inserted. Electrotransformation into CK111/pCF10-101 was performed as previously described. Overnight cultures of the donor strain (CK111/pCF10-101, pCJK47-derivatives) and recipient strain (M1TC; E. faecalis FA2-2 transconjugants of M1 strain) were diluted 100-fold into fresh THB broth and incubated separately at $37^{\circ} \mathrm{C}$ for $1 \mathrm{~h}$. One hundred microliter aliquots of the donor and recipient cultures were mixed with $800 \mu \mathrm{l}$ of fresh THB broth and incubated at $37^{\circ} \mathrm{C}$ with shaking at $150 \mathrm{rpm}$ for $12 \mathrm{~h}$, and were then spread on a BHI plate (rifampicin $25 \mathrm{mg} / \mathrm{L}$, fusidic acid $25 \mathrm{mg} / \mathrm{L}$, erythromycin $10 \mathrm{mg} / \mathrm{L}$ and X-gal $100 \mathrm{mg} / \mathrm{L}$ ). After incubation at $37^{\circ} \mathrm{C}$ for $32-48 \mathrm{~h}$, colonies that were blue in color were isolated and purified as these were expected to be integrant clones where the $\mathrm{pCJK} 47$-derivative plasmid had integrated into the chromosomal target locus of the recipient strain. These integrant clones were inoculated in THB and incubated at $37^{\circ} \mathrm{C}$ for $12 \mathrm{~h}$. After a 100 -fold dilution, $100 \mu \mathrm{l}$ of the culture broth was plated on an MM9YEG plate supplemented with $10 \mathrm{mM}$ 4-Chloro-DL-phenylalanine (SIGMA-ALDRICH Co., MO) and $40 \mathrm{mg} / \mathrm{L} \mathrm{X-gal,} \mathrm{followed}$ by incubation at $37^{\circ} \mathrm{C}$ for $12 \mathrm{~h}$. White colonies were then isolated and purified as potential candidates carrying mutations within the target genes. The nucleotide sequences were checked to determine whether the desired nucleotide substitution had occurred in the target sequences. 


\section{Additional files}

Additional file 1: Table S1. Amino acid identities of vanB gene cluster of wild $\mathrm{M} 1$ and $\mathrm{Y} 7$ strains. ${ }^{\top}$ The genetic information for VanB-type vancomycin resistant enterococci was obtained from the genome database in NCBI (http://www.ncbi.nlm.nih.gov/). MLG29 (accession no.; AY655721.2), UW7606×64/3 TC1 (accession no.; CP013009.1), V583 (accession no.; NC_004668), Aus0085 (accession no.; NC_021994.1), BM4661 (accession no.; FJ767776.1). ${ }^{~ I}$ Identities were calculated by ClustalW [45]. (XLSX 11 kb)

Additional file 2: Figure S1. Amino acid sequence alignment of $\operatorname{VanS}_{B}$ encoded by M1/Y7 and the other VanB-type VRE. The genetic information for VanB-type vancomycin resistant enterococci was obtained from the genome database in NCBI (http://www.ncbi.nlm.nih.gov/). Alignments of $V_{a n S} S_{B}$ amino acid sequence of wild M1/Y7 with typical VanB-type vancomycin resistant enterococci such as MLG229 (accession no.; AY655721.2), UW7606x64/3 TC1 (accession no.; CP013009.1), V583 (accession no.; NC_004668), Aus0085 (accession no.;NC_021994.1) and BM4661 (accession no.; FJ767776.1) were carried out using ClustalW. A box indicated the unique substitution to M1 / Y7 strains. (DOCX $116 \mathrm{~kb}$ )

Additional file 3: Figure S2. Amino acid sequence alignment of VanB encoded by M1/Y7 and the other VanB-type VRE. The genetic information for VanB-type vancomycin resistant enterococci was obtained from the genome database in NCBI (http://www.ncbi.nlm.nih.gov/). Alignments of VanB amino acid sequence of wild M1/Y7 with typical VanB-type vancomycin resistant enterococci such as MLG229 (accession no.; AY655721.2), UW7606x64/3 TC1 (accession no.; CP013009.1), V583 (accession no.; NC_004668), Aus0085 (accession no.;NC_021994.1) and BM4661 (accession no.; FJ767776.1) were carried out using ClustalW. A box indicated the unique substitution to M1 /Y7 strains. (DOCX 94 kb)

Additional file 4: Figure S3. Amino acid sequence alignment of VanW encoded by M1/Y7 and the other VanB-type VRE. The genetic information for VanB-type vancomycin resistant enterococci was obtained from the genome database in NCBI (http://www.ncbi.nlm.nih.gov/). Alignments of VanW amino acid sequence of wild M1/Y7 with typical VanB-type vancomycin resistant enterococci such as MLG229 (accession no.; AY655721.2), UW7606x64/3 TC1 (accession no.; CP013009.1), V583 (accession no.; NC_004668), Aus0085 (accession no.;NC_021994.1) and BM4661 (accession no.; FJ767776.1) were carried out using ClustalW. A box indicated the unique substitution to M1 /Y7 strains. (DOCX 85 kb)

Additional file 5: Figure S4. PFGE of S1 nuclease-treated DNA and hybridization with vanB gene probes. PFGE of S1 nuclease-treated DNAs isolated from M1, Y7, M1TC, Y7TC, FA2-2 and V583 was performed (Left) and separated DNAs were transferred to Nylon membrane by Southern blotting and hybridized to vanB gene probe (Right). Lanes: MM, Lambda Ladder PFG Marker (New England BioLabs, MA); 1, M1; 2, Y7; 3, M1TC; 4, Y7TC; 5, FA2-2; 6, V583. (DOCX 600 kb)

Additional file 6: Figure S5. PFGE of I-Ceul-digested DNA and hybridization with 23srRNA gene and $v a n B$ gene probes. PFGE of I-Ceul-digested DNAs isolated from M1, Y7, M1TC, Y7TC, FA2-2 and V583 was performed (Left) and separated DNAs were transferred to Nylon membrane by Southern blotting and hybridized to $23 \mathrm{~s}$ rRNA gene prove (Middle) and vanB gene probe (Right). Lanes: MM, Lambda Ladder PFG Marker (New England BioLabs, MA); 1, M1; 2, Y7; 3, M1TC; 4, Y7TC; 5, FA2-2; 6, V583. (DOCX 411 kb)

Additional file 7: Table S2. Mutations in intracytoplasmic domain of $\mathrm{VanS}_{\mathrm{B}}$ and glycopeptides MICs of the VAN-resistant revertants. ${ }^{a} \mathrm{M} 1 \mathrm{R} 1-\mathrm{M} 1 \mathrm{R} 17$ revertants from $\mathrm{M} 1, \mathrm{Y} 7 \mathrm{R} 1-7$; revertants from $\mathrm{Y} 7 .{ }^{\circ}$ The sequence was compared with the vanB gene cluster of the cognate parent strain, M1 or Y7. ${ }^{~ V A N:}$ vancomycin, TEC: teicoplanin. N. D.; not detected. (XLSX 11 kb)

Additional file 8: Table S3. Oligonucleotides used in this study. ${ }^{a}$ Small letters indicate additional tag-nucleotides for plasmid construction to be digested by restriction. (XLSX $11 \mathrm{~kb}$ )

\section{Abbreviations}

AMP: ampicillin; BAPS: Bayesian analysis of population structure; CFU: colonyforming unit; CHL: hloramphenicol; CIP: ciprofloxacin; CLSI: Clinical and Laboratory Standards Institutes; ERY: erythromycin; EUCAST: European Committee on Antimicrobial Susceptibility Testing for enterococci; GEN: gentamicin; KAN: kanamycin; MIC: minimum inhibitory concentration;
MLST: multilocus sequence typing; PFGE: pulsed-field gel electrophoresis; SNV: single nucleotide variation; STR: streptomycin; TEC: teicoplanin; TET: tetracycline; VAN: vancomycin; VRE: vancomycin resistant enterococci; WE: vancomycin variable Enterococcus faecium

\section{Acknowledgments}

Not applicable.

\section{Funding}

This work was supported by grants from the Japanese Ministry of Education, Culture, Sport, Science and Technology [Grant-in-Aid for Young Scientists (B) 25870116, Gunma University Operation Grants] and the Japanese Ministry of Health, Labor and Welfare (the Research Program on Emerging and Re-emerging Infectious Diseases from the Japan Agency for Medical Research and Development [AMED], H27-Shokuhin-Ippan-008). The funding agencies had no role in the design of the study, collection, data analysis, data interpretation, or the writing of this manuscript.

Availability of data and materials

All data and materials are provided in the article (and its supplementary information).

\section{Authors' contributions}

The project was conceived and designed by YH, JK, TN, KT1, KT2, HY, KS, Y and HT. The clinical materials were collected and provided by KT2, HY and KS. Antibiotic susceptibility test, conjugation experiment and PFGE analysis were conducted by $\mathrm{YH}$ and TN. Targeted mutagenesis was conducted by $\mathrm{YH}$ and JK. All the other works were conducted by $\mathrm{YH}$. The final manuscript was written by $\mathrm{YH}, \mathrm{KT} 1$ and $\mathrm{HT}$. All authors read and approved the final manuscript. (KT1: Koichi Tanimoto, KT2: Kiyoko Tamai)

Ethics approval and consent to participate

Not applicable.

\section{Consent for publication}

Not applicable.

\section{Competing interests}

The authors declare that they have no competing interests.

\section{Publisher's Note}

Springer Nature remains neutral with regard to jurisdictional claims in published maps and institutional affiliations.

\section{Author details}

'Department of Bacteriology, Gunma University Graduate School of Medicine, 3-39-22 Showa-machi, Maebashi, Gunma 371-8511, Japan. ${ }^{2}$ Laboratory of Bacterial Drug Resistance, Gunma University Graduate School of Medicine, 3-39-22 Showa-machi, Maebashi, Gunma 371-8511, Japan.

${ }^{3}$ MIROKU Medical Laboratory Inc, 659-2 Innai, Saku, Nagano 384-2201, Japan.

${ }^{4}$ Yamaguchi Prefectural Institute of Public Health and Environment, 2-5-67

Aoi, Yamaguchi, Yamaguchi 753-0821, Japan.

Received: 14 May 2018 Accepted: 14 November 2018

Published online: 13 December 2018

\section{References}

1. Arthur M, Reynolds P, Courvalin P. Glycopeptide resistance in enterococci. Trends Microbiol. 1996:4(10):401-7.

2. Hollenbeck $B L$, Rice LB. Intrinsic and acquired resistance mechanisms in enterococcus. Virulence. 2012:3(5):421-33.

3. Leclercq R, Derlot E, Duval J, Courvalin P. Plasmid-mediated resistance to vancomycin and teicoplanin in enterococcus faecium. N Engl J Med. 1988, 319(3):157-61.

4. Uttley $\mathrm{AH}$, Collins $\mathrm{CH}$, Naidoo J, George RC: Vancomycin-resistant enterococci. Lancet (London, England) 1988, 1(8575-6):57-58.

5. Werner G, Coque TM, Hammerum AM, Hope R, Hryniewicz W, Johnson A, Klare I, Kristinsson $\mathrm{KG}$, Leclercq $\mathrm{R}$, Lester $\mathrm{CH}$ et al: Emergence and spread of vancomycin resistance among enterococci in Europe. Euro Surveill 2008, 13 (47).

6. Wijesuriya TM, Perry P, Pryce T, Boehm J, Kay I, Flexman J, Coombs GW Ingram PR. Low vancomycin MICs and fecal densities reduce the sensitivity 
of screening methods for vancomycin resistance in enterococci. J Clin Microbiol. 2014;52(8):2829-33.

7. Courvalin P: Vancomycin resistance in gram-positive cocci. Clinical Infectious Disease 2006, 42(Supple1):S25-S34.

8. Evers $\mathrm{S}$, Courvalin P. Regulation of VanB-type vancomycin resistance gene expression by the $\operatorname{VanS}(\mathrm{B})-\operatorname{VanR}(\mathrm{B})$ two-component regulatory system in enterococcus faecalis V583. J Bacteriol. 1996;178(5):1302-9.

9. Werner G, Klare I, Fleige C, Geringer U, Witte W, Just HM, Ziegler R. Vancomycin-resistant vanB-type enterococcus faecium isolates expressing varying levels of vancomycin resistance and being highly prevalent among neonatal patients in a single ICU. Antimicrob Resist Infect Control. 2012;1(1):21.

10. Freitas AR, Tedim AP, Francia MV, Jensen LB, Novais C, Peixe L, SanchezValenzuela A, Sundsfjord A, Hegstad K, Werner G, et al. Multilevel population genetic analysis of vanA and vanB enterococcus faecium causing nosocomial outbreaks in 27 countries (1986-2012). J Antimicrob Chemother. 2016;71(12):3351-66.

11. Hegstad K, Giske CG, Haldorsen B, Matuschek E, Schonning K, Leegaard TM, Kahlmeter G, Sundsfjord A, Nordic ASTVREDSG. Performance of the EUCAST disk diffusion method, the CLSI agar screen method, and the Vitek 2 automated antimicrobial susceptibility testing system for detection of clinical isolates of enterococci with low- and medium-level VanB-type vancomycin resistance: a multicenter study. J Clin Microbiol. 2014;52(5):1582-9.

12. Coburn B, Low DE, Patel SN, Poutanen SM, Shahinas D, Eshaghi A, Willey BM, McGeer A. Vancomycin-variable enterococcus faecium: in vivo emergence of vancomycin resistance in a vancomycin-susceptible isolate. J Clin Microbiol. 2014;52(5):1766-7.

13. Thaker MN, Kalan L, Waglechner N, Eshaghi A, Patel SN, Poutanen S, Willey B, Coburn B, McGeer A, Low DE, et al. Vancomycin-variable enterococci can give rise to constitutive resistance during antibiotic therapy. Antimicrob Agents Chemother. 2015;59(3):1405-10.

14. Sivertsen A, Pedersen T, Larssen KW, Bergh K, Ronning TG, Radtke A, Hegstad K. A silenced vanA gene cluster on a transferable plasmid caused an outbreak of vancomycin-variable enterococci. Antimicrob Agents Chemother. 2016;60(7):4119-27.

15. Fujita N, Yoshimura M, Komori T, Tanimoto K, Ike Y. First report of the isolation of high-level vancomycin-resistant enterococcus faecium from a patient in Japan. Antimicrob Agents Chemother. 1998;42(8):2150.

16. Zheng B, Tomita $H$, Inoue $T$, Ike $Y$. Isolation of VanB-type enterococcus faecalis strains from nosocomial infections: first report of the isolation and identification of the pheromone-responsive plasmids pMG2200, encoding VanB-type vancomycin resistance and a Bac41-type bacteriocin, and pMG2201, encoding erythromycin resistance and cytolysin (Hly/bac). Antimicrob Agents Chemother. 2009;53(2):735-47.

17. San Millan A, Depardieu F, Godreuil S, Courvalin P. VanB-type enterococcus faecium clinical isolate successively inducibly resistant to, dependent on, and constitutively resistant to vancomycin. Antimicrob Agents Chemother. 2009;53(5):1974-82.

18. Sahm DF, Kissinger J, Gilmore MS, Murray PR, Mulder R, Solliday J, Clarke B. In vitro susceptibility studies of vancomycin-resistant enterococcus faecalis. Antimicrob Agents Chemother. 1989;33(9):1588-91.

19. Ballard SA, Pertile KK, Lim M, Johnson PD, Grayson ML. Molecular characterization of vanB elements in naturally occurring gut anaerobes. Antimicrob Agents Chemother. 2005;49(5):1688-94.

20. Lam MM, Seemann T, Tobias NJ, Chen H, Haring V, Moore RJ, Ballard S, Grayson LM, Johnson PD, Howden BP, et al. Comparative analysis of the complete genome of an epidemic hospital sequence type 203 clone of vancomycin-resistant enterococcus faecium. BMC Genomics. 2013;14:595.

21. Bender JK, Kalmbach A, Fleige C, Klare I, Fuchs S, Werner G. Population structure and acquisition of the vanB resistance determinant in German clinical isolates of enterococcus faecium ST192. Sci Rep. 2016;6:21847.

22. Andersson DI, Levin BR. The biological cost of antibiotic resistance. Curr Opin Microbiol. 1999;2(5):489-93.

23. Foucault ML, Depardieu F, Courvalin P, Grillot-Courvalin C. Inducible expression eliminates the fitness cost of vancomycin resistance in enterococci. Proc Natl Acad Sci U S A. 2010;107(39):16964-9.

24. Willems RJ, Top J, van Schaik W, Leavis H, Bonten M, Siren J, Hanage WP, Corander J. Restricted gene flow among hospital subpopulations of enterococcus faecium. MBio. 2012;3(4):e00151-12.

25. Willems RJ, Top J, van Santen M, Robinson DA, Coque TM, Baquero F, Grundmann H, Bonten MJ. Global spread of vancomycin-resistant enterococcus faecium from distinct nosocomial genetic complex. Emerg Infect Dis. 2005;11(6):821-8.
26. Howden BP, Holt KE, Lam MM, Seemann T, Ballard S, Coombs GW, Tong SY, Grayson ML, Johnson PD, Stinear TP. Genomic insights to control the emergence of vancomycin-resistant enterococci. MBio. 2013;4(4).

27. Matsushima A, Takakura S, Yamamoto M, Matsumura Y, Shirano M, Nagao M, Ito $Y$, linuma $Y$, Shimizu T, Fujita N, et al. Regional spread and control of vancomycin-resistant enterococcus faecium and enterococcus faecalis in Kyoto, Japan. Eur J Clin Microbiol Infect Dis. 2012;31(6):1095-100.

28. Normark BH, Normark S. Evolution and spread of antibiotic resistance. J Intern Med. 2002;252(2):91-106.

29. Depardieu F, Podglajen I, Leclercq R, Collatz E, Courvalin P. Modes and modulations of antibiotic resistance gene expression. Clin Microbiol Rev. 2007;20(1):79-114.

30. Marshall CG, Broadhead G, Leskiw BK, Wright GD. D-ala-D-ala ligases from glycopeptide antibiotic-producing organisms are highly homologous to the enterococcal vancomycin-resistance ligases VanA and VanB. Proc Natl Acad Sci U S A. 1997;94(12):6480-3.

31. Roper DI, Huyton T, Vagin A, Dodson G. The molecular basis of vancomycin resistance in clinically relevant enterococci: crystal structure of D-alanyl-Dlactate ligase (VanA). Proc Natl Acad Sci U S A. 2000;97(16):8921-5.

32. Liu S, Chang JS, Herberg JT, Horng MM, Tomich PK, Lin AH, Marotti KR. Allosteric inhibition of Staphylococcus aureus D-alanine:D-alanine ligase revealed by crystallographic studies. Proc Natl Acad Sci U S A. 2006;103(41):15178-83.

33. Silva JC, Haldimann A, Prahalad MK, Walsh CT, Wanner BL. In vivo characterization of the type a and B vancomycin-resistant enterococci (VRE) VanRS two-component systems in Escherichia coli: a nonpathogenic model for studying the VRE signal transduction pathways. Proc Natl Acad Sci U S A. 1998;95(20):11951-6.

34. Kristich CJ, Djoric D, Little JL. Genetic basis for vancomycin-enhanced cephalosporin susceptibility in vancomycin-resistant enterococci revealed using counterselection with dominant-negative thymidylate synthase. Antimicrob Agents Chemother. 2014;58(3):1556-64.

35. Nomura T, Tanimoto K, Shibayama K, Arakawa Y, Fujimoto S, Ike Y, Tomita $\mathrm{H}$. Identification of VanN-type vancomycin resistance in an enterococcus faecium isolate from chicken meat in Japan. Antimicrob Agents Chemother. 2012:56(12):6389-92.

36. Tenover FC, Arbeit RD, Goering RV, Mickelsen PA, Murray BE, Persing DH, Swaminathan B. Interpreting chromosomal DNA restriction patterns produced by pulsed-field gel electrophoresis: criteria for bacterial strain typing. J Clin Microbiol. 1995;33(9):2233-9.

37. Dicuonzo G, Gherardi G, Lorino G, Angeletti S, Battistoni F, Bertuccini L, Creti R, Di Rosa R, Venditti M, Baldassarri L. Antibiotic resistance and genotypic characterization by PFGE of clinical and environmental isolates of enterococci. FEMS Microbiol Lett. 2001;201(2):205-11.

38. Valdezate S, Labayru C, Navarro A, Mantecon MA, Ortega M, Coque TM, Garcia M, Saez-Nieto JA. Large clonal outbreak of multidrug-resistant CC17 ST17 enterococcus faecium containing Tn5382 in a Spanish hospital. J Antimicrob Chemother. 2009;63(1):17-20.

39. Green M, Sambrook J. Molecular cloning: a laboratory manual; 2012.

40. Dahl KH, Sundsfjord A. Transferable vanB2 Tn5382-containing elements in fecal streptococcal strains from veal calves. Antimicrob Agents Chemother. 2003;47(8):2579-83.

41. Homan WL, Tribe D, Poznanski S, Li M, Hogg G, Spalburg E, Van Embden JD Willems RJ. Multilocus sequence typing scheme for enterococcus faecium. J Clin Microbiol. 2002;40(6):1963-71.

42. Dunny GM, Brown BL, Clewell DB. Induced cell aggregation and mating in Streptococcus faecalis: evidence for a bacterial sex pheromone. Proc Natl Acad Sci U S A. 1978;75(7):3479-83.

43. Kristich CJ, Chandler JR, Dunny GM. Development of a host-genotypeindependent counterselectable marker and a high-frequency conjugative delivery system and their use in genetic analysis of enterococcus faecalis. Plasmid. 2007;57(2):131-44.

44. Dutta R, Qin L, Inouye M. Histidine kinases: diversity of domain organization. Mol Microbiol. 1999;34(4):633-40.

45. Thompson JD, Higgins DG, Gibson TJ. CLUSTAL W: improving the sensitivity of progressive multiple sequence alignment through sequence weighting, position-specific gap penalties and weight matrix choice. Nucleic Acids Res. 1994;22(22):4673-80. 